ЕНЕРГЕТИКА. ТЕПЛОТЕХНІКА.

ЕЛЕКТРОТЕХНІКА

UDC 622.276.65

V.P. Kravchenko, DEng, Prof.,

O.M. Sorokin

Odessa National Polytechnic University, 1 Shevchenko Ave., 65044 Odessa, Ukraine; e-mail: vpkrav54@i.ua

\title{
DETERMINATION OF ECONOMIC FEASIBILITY OF HEAT SUPPLY FROM NPP FOR OILFIELD
}

\begin{abstract}
В.П. Кравченко, О.М. Сорокін. Визначення економічної доцільності забезпечення теплопостачання нафтового родовища від ядерної енергетичної установки. Видобуток нафти в Україні постійно знижується. У цих умовах є доцільним використовувати третинні методи інтенсифікації нафтовидобування, що збільшують рухливість нафти. До них відноситься метод, заснований на закачуванні в пласт гарячого теплоносія для підвищення температури нафти, що призведе до зниження ії в'язкості і збільшення рухливості. Mema: Метою роботи є техніко-економічне обгрунтування доцільності побудови і використання ядерного нафтовидобувного комплексу з метою підвищення нафтовидобування на родовищах, що знаходяться в пізній стадії розробки, на прикладі Охтирського родовища (Україна). Матеріали і методи: Охтирське родовище вважається найперспективнішим в Україні. Виявлений сировинний потенціал може забезпечити стабільний видобуток нафти близько 2 млн. т щорічно протягом $50 \ldots 60$ років. За результатом аналізу схеми розташування видобувних свердловин, проведеного на підставі аерокосмічних знімків, виділено три групи свердловин. 3 урахуванням рози вітрів було визначено оптимальне розташування атомної електростанції відносно р. Охтирка. Запропоновано для забезпечення потреб нафтогазовидобувного підприємства використовувати серійний блок атомної електростанції з реактором ВВЕР-1000. Результати: Було розроблено і розраховано схему теплофікаційної установки для турбіни К-1000-5,8/50, що забезпечуе підготовку технологічного теплоносія, який закачують в нагнітальні свердловини. Розроблено схему і визначено основні конструктивні характеристики теплової мережі для доставки технологічного теплоносія від АЕС до свердловин. Визначено, що при витраті теплоносія зі швидкістю 675 т/год. електрична потужність блоку дорівнює 935,6 МВт. В результаті розрахунку прибутку від продажу електроенергії і додаткової нафти за рік з урахуванням річних експлуатаційних витрат було визначено прибуток в розмірі 1063,37 млн. USD.
\end{abstract}

Ключові слова: ядерний нафтовидобувний комплекс, теплова мережа, приведені витрати.

V.P. Kravchenko, O.M. Sorokin. Determination of economic feasibility of heat supply from NPP for oilfield. The oil production in Ukraine is constantly decreasing. In these conditions it is appropriate to use tertiary methods of intensifying in oil production which increase the mobility of oil. These include a method based on injection into the layer a hot water to raise the temperature of oil that lead to a decrease its viscosity and increase mobility. Aim: The aim of this research is a technical economic feasibility study of constructing and using the nuclear power complex for oil production in order to increase the oil extraction from oilfields in their late stages of production by the example of Okhtyrka oilfield (Ukraine). Materials and Methods: Okhtyrka oilfield is considered the most promising in Ukraine. The explored raw material potential can provide the stable oil production about 2 millions tones annually during $50 \ldots 60$ years. On the basis of aerospace photos the oilfield can be divided into three areas which are called North, Central and South. The possible nuclear power plant location selected on the basis of wind rose relative Okhtyrka city and heating networks scheme from NPP to the injection wells. Results: It was developed and designed the key diagram of turbine plant K-1000-5,8/50 with a cogeneration plant which provide the technological coolant for injection into the wells. In rated mode the turbine with cogeneration plant provides $675 \mathrm{t} / \mathrm{h}$ of technological coolant at temperature of $250{ }^{\circ} \mathrm{C}$ and has electrical power $935.6 \mathrm{MW}$. As a result of calculating the profit from the sale of electricity and additional oil per year with account of annual operating costs, we determine that the profit equal to 1063.37 millions USD.

Keywords: nuclear power complex for oil production, heating network, reduced costs.

Introduction. The average ultimate oil fields output in different countries and regions ranges from $25 \%$ to $40 \%$ [1]. Therefore to improve the efficiency of oilfields is an actual task today. The studies, which were conducted in Ukraine, shown that using the thermal methods increases oil produc- 
tion more than three times, but other sources provide more modest estimate. So, in [2] indicated that using of thermal methods will increase oil output by $11 \ldots 33 \%$. For this purpose today the steam generators are installing directly at the wells (US [3]) or, for example, nuclear power plants (NPP) are building to ensure production of viscous oil by coolant (Canada [4]).

After 1972 oil production in Ukraine is constantly decreasing. This is primarily due to the large output of reserves in major oilfields, and their entry in the late stages of development, which is accompanied by a high percentage of water in wells and reduce their production.

In these conditions it is appropriate to use tertiary methods of intensifying in oil production [4], which increase the mobility of oil. These techniques can increase the rate of production of oil up to $60 . .70 \%$. These include a method based on injection into the layer a hot water to raise the temperature of oil that lead to a decrease its viscosity and increase mobility. In turn, J. Burger et al. [5], and N.K. Baibakov [6] stated that for the preparation of hot water for further injection into a layer, it is advisable to use nuclear power plants.

The aim of this research is a technical economic feasibility study of constructing and using the nuclear power complex for oil production in order to increase the oil extraction from oilfields in their late stages of production by the example of Okhtyrka oilfield (Ukraine).

The nuclear power complex for oil production consists of NPP, heating networks, which deliver technology coolant (TC), that is hot water, to the injection wells.

\section{Materials and Methods.}

Development of heating networks scheme for Okhtyrka oilfield. Okhtyrka oilfield is considered the most promising in Ukraine, but the existing resource base can not guarantee significant growth of oil and gas. Today has been a steady drop in oil production in most of the oilfields in Ukraine on $5 . . .15 \%$ annually. In this sharp decline in funding for geological research and the rising cost of operations in recent years have led to the reduction of deep prospect drilling. Hence the need to use of modern technologies of production. According to specialists of JSC "Ukrnafta", the explored raw material potential can provide the stable oil production about $2 \mathrm{mln}$. tones annually during $50 \ldots 60$ years [7].

Capacity of the Okhtyrka oilfield currently is 135 tonnes per hour. Based on the accepted value of $5 \mathrm{~m}^{3}$ hot water per $1 \mathrm{~m}^{3}$ of oil, i.e. the technology coolant consumption is 675 tonnes per hour.

On the basis of aerospace photos the oilfield can be divided into three areas (Fig. 1), which are called Northern, Central and South. Fig. 1 shows a possible nuclear power plant location selected on the basis of wind rose relative Okhtyrka city and heating networks scheme from NPP to the injection wells. Table 1 shows the main characteristics of the area. Capacity of each area is defined by the number of wells, and average capacity of 18.75 tons per day.

Methods of the technical economic comparison. The reduced costs adopted as a comparison criterion [8]:

$$
E A C=R O I \cdot C A P E X+O C,
$$

where $R O I-$ return on investment index, $R O I=0.12$;

$C A P E X$ - capital expenditure;

$O C$ - annual operating costs $[8,9]$.

Annual operating costs calculated by the following formula:

$$
O C=O C_{f u e l}+O C_{e e}+O C_{t w}+O C_{i n v}+O C_{o p},
$$

where $O C_{f u e l}-$ annual costs for fuel:

$$
O C_{\text {fuel }}=A C_{\text {fuel }} \cdot C_{\text {fuel }}
$$

$C_{\text {fuel }}$ - fuel costs (700 thou. USD);

$A C_{\text {fuel }}$ - annual fuel consumption (41 cassettes);

$O C_{e e}$ - annual costs for electric energy:

$$
O C_{e e}=A C_{e e} \cdot C_{e e},
$$

$C_{e e}-$ cost of electricity, $C_{\mathrm{ee}}=0.04 \mathrm{USD} / \mathrm{kWh}$; 
$A C_{e e}$ - annual electricity consumption, $\mathrm{kWh}$;

$O C_{t w}$ - cost of raw water treating $\left(O C_{t w}=0.3 \mathrm{USD} / \mathrm{m}^{3}\right)$;

$O C_{i n v}$ - annual depreciation costs of capital investment and maintenance:

$$
O C_{i n v}=D_{r} \cdot C A P E X+O C_{r e p}=D_{r} \cdot C A P E X+0.1 \cdot D_{r} \cdot C A P E X=1.1 \cdot D_{r} \cdot C A P E X \text {, }
$$

$D_{r} \cdot C A P E X$ - depreciation costs (depreciation rate $D_{r}$ is 0.06 );

$O C_{\text {rep }}-$ cost of current repairs $(10 \ldots 20 \%$ of depreciation costs [9]);

$O C_{o p}$ - annual costs for personnel and other general expenses:

$$
O C_{o p}=1.2 \cdot O C_{\text {pers }}+0.22 \cdot D_{r} \cdot C A P E X,
$$

where $O C_{\text {pers }}$ - annual personnel costs.

Considering that personnel costs at facilities which compare are equal, however, these costs in variable part of the resulted expenses can be ignored. Then the final formula for the variable part of these expenses is as follows:

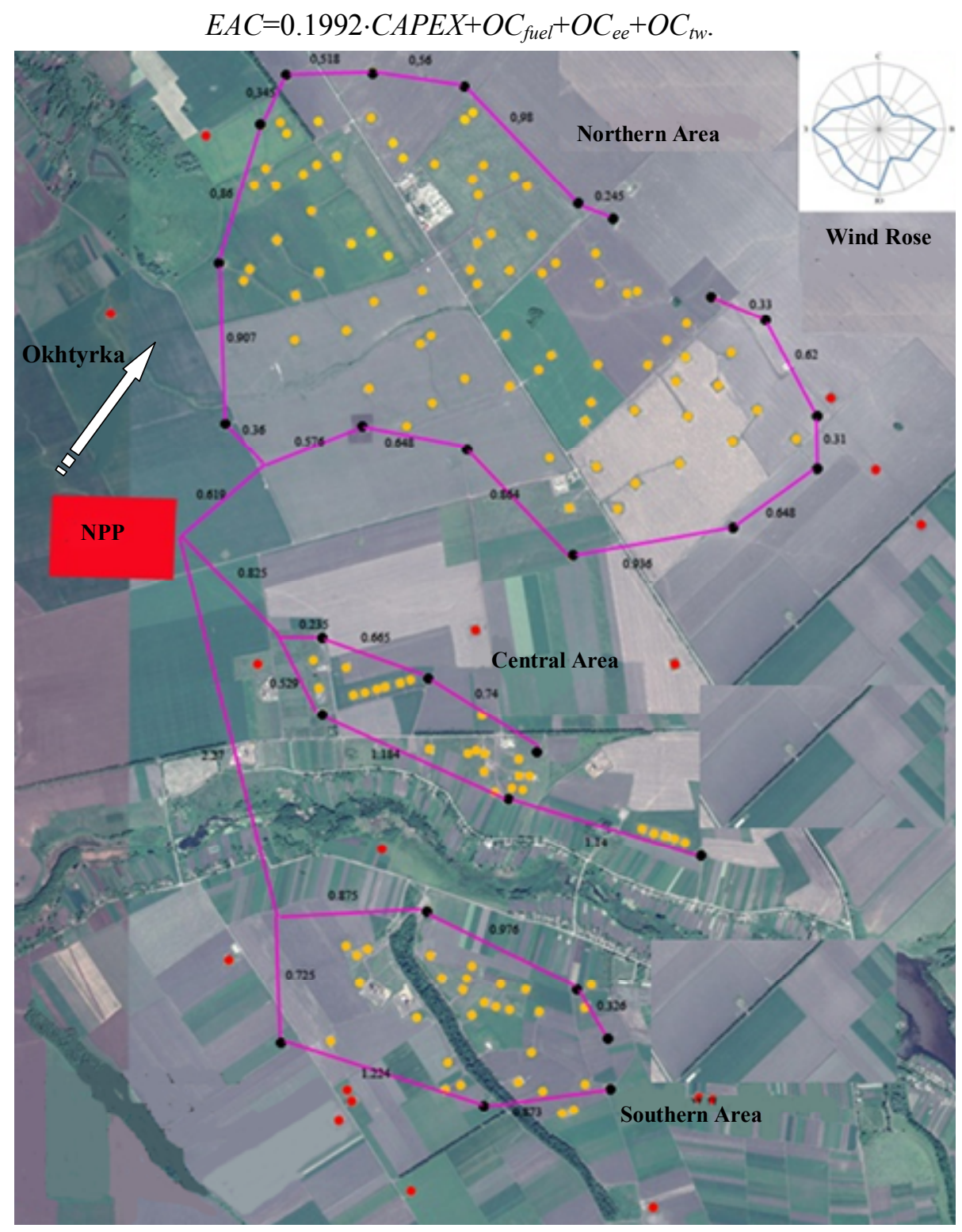

Fig. 1. Location of wells at Okhtyrka oilfield (distance between the injection wells in km) 
Table 1

Characteristics of the oilfield areas

\begin{tabular}{l|c|c|c}
\hline \multicolumn{1}{c|}{ Area } & Number of producing wells & Production of oil, $\mathrm{m}^{3} / \mathrm{h}$ & Estimated TC consumption, $\mathrm{m}^{3} / \mathrm{h}$ \\
\hline Northern & 99 & 74.25 & 371.25 \\
\hline Central & 35 & 26.25 & 131.25 \\
\hline Southern & 46 & 34.5 & 172.5 \\
\hline
\end{tabular}

The calculation of the heating networks "NPP - injection wells". According to the scheme of heating networks shown in Fig. 1, we prepared algorithm and conducted the calculation of the resulted expenses in thermal network that consists of three sections. Each section consists of two branches southern and northern.

We calculated the heating networks considering the following characteristics:

- diameters and cost of pipelines;

- number, power and cost of pumps;

- cost of thermal insulation;

- energy costs for pumping of coolant.

Algorithm of hydraulic calculation and determination of the costs of pipelines, pumps and thermal insulation are given in [10]. When calculating the network the diameters of pipelines at each site were selected in terms of the minimum reduced costs.

The results of calculating the costs of pipes, pumps and insulation, as well as the required pumps power with optimum diameters of pipelines are shown in Table 2.

Table 2

The results of calculation of the main characteristics of heating networks

\begin{tabular}{l|c|c|c|c|c|c|c|c|c}
\hline $\begin{array}{c}\text { Oilfield } \\
\text { area }\end{array}$ & $\begin{array}{c}\text { Coolant } \\
\text { consumption, } \\
\mathrm{t} / \mathrm{h}\end{array}$ & $\begin{array}{c}\text { The length } \\
\text { of the TC } \\
\text { pipelines, } \mathrm{m}\end{array}$ & $\begin{array}{c}\mathrm{TC} \\
\text { temperature } \\
\text { at the } \\
\text { entrance to } \\
\text { the well, }{ }^{\circ} \mathrm{C}\end{array}$ & $\begin{array}{c}\mathrm{TC} \\
\text { temperature } \\
\text { at the exit } \\
\text { from the } \\
\text { well, }{ }^{\circ} \mathrm{C}\end{array}$ & $\begin{array}{c}\mathrm{TC} \\
\text { pipelines } \\
\text { costs, USD }\end{array}$ & $\begin{array}{c}\text { Pump } \\
\text { costs, USD }\end{array}$ & $\begin{array}{c}\text { Thermal } \\
\text { insulation } \\
\text { costs, USD }\end{array}$ & $\begin{array}{c}\text { The cost of } \\
\text { electricity } \\
\text { for pump- } \\
\text { ing, USD/h }\end{array}$ & $\begin{array}{c}\text { Reduced } \\
\text { costs, } \\
\text { USD/year }\end{array}$ \\
\hline Northern & 371.25 & 10326 & 236 & 221.5 & 71313 & 25715 & 15474 & 17177 & 39588 \\
\hline Central & 131.25 & 5319 & 242.85 & 227.4 & 18702 & 4767 & 8451 & 5003 & 11361 \\
\hline Southern & 172.5 & 7269 & 238.4 & 226.65 & 36901 & 7373 & 15255 & 10969 & 22827 \\
\hline Total & $\mathbf{6 7 5}$ & $\mathbf{2 2 2 9 5}$ & $\mathbf{2 3 8}$ & $\mathbf{2 2 3 . 9}$ & $\mathbf{1 2 6 9 1 6}$ & $\mathbf{3 7 8 5 5}$ & $\mathbf{3 9 1 8 0}$ & $\mathbf{3 3 1 4 9}$ & $\mathbf{7 3 7 7 6}$ \\
\hline
\end{tabular}

The calculation of cogeneration plant for TC preparation. The key diagram of turbine plant $\mathrm{K}-1000-5,8 / 50$ with a cogeneration plant is shown in Fig. 2 . The results of calculation of parameters in key points of cogeneration plant are shown in Table 3.

Table 3

The main parameters of cogeneration plant

\begin{tabular}{l|c|c|c|c|c|c|c}
\hline Heater & $\begin{array}{c}\mathrm{G} \text { of } \\
\text { steam, } \\
\mathrm{kg} / \mathrm{s}\end{array}$ & $\begin{array}{c}\text { Temperature } \\
\text { of steam, }{ }^{\circ} \mathrm{C}\end{array}$ & $\begin{array}{c}\text { Pressure of } \\
\text { steam, } \\
\mathrm{MPa}\end{array}$ & $\begin{array}{c}\mathrm{TC} \\
\text { temperature } \\
\text { at entrance, } \\
{ }^{\circ} \mathrm{C}\end{array}$ & $\begin{array}{c}\text { TC } \\
\text { temperature } \\
\text { at exit, }{ }^{\circ} \mathrm{C}\end{array}$ & $\begin{array}{c}\text { TC enthalpy at } \\
\text { entrance, } \mathrm{kJ} / \mathrm{kg}\end{array}$ & $\begin{array}{c}\text { TC enthalpy at } \\
\text { exit, } \mathrm{kJ} / \mathrm{kg}\end{array}$ \\
\hline PSV1 & 4.982 & 66.5 & 0.024 & 30 & 50 & 157.1 & 268.8 \\
\hline TH1 & 3.687 & 88.9 & 0.061 & 50 & 86.4 & 268.8 & 345.9 \\
\hline TH2 & 3.933 & 130.9 & 0.121 & 86.4 & 126.4 & 345.9 & 423.7 \\
\hline TH3 & 4.601 & 188.81 & 0.249 & 126.4 & 182.7 & 423.7 & 516.7 \\
\hline TH4 & 12.649 & 158.8 & 0.564 & 182.7 & 156.4 & 516.7 & 642.8 \\
\hline TH5 & 5.185 & 177.2 & 0.893 & 156.4 & 175 & 642.8 & 687.7 \\
\hline TH6 & 9.213 & 198.3 & 1.44 & 175 & 196.4 & 687.7 & 806 \\
\hline TH7 & 12.269 & 222.9 & 2.377 & 196.4 & 221.3 & 806 & 935.1 \\
\hline TH8 & 15.46 & 272 & 5.8 & 221.3 & 250 & 935.1 & 1085 \\
\hline
\end{tabular}




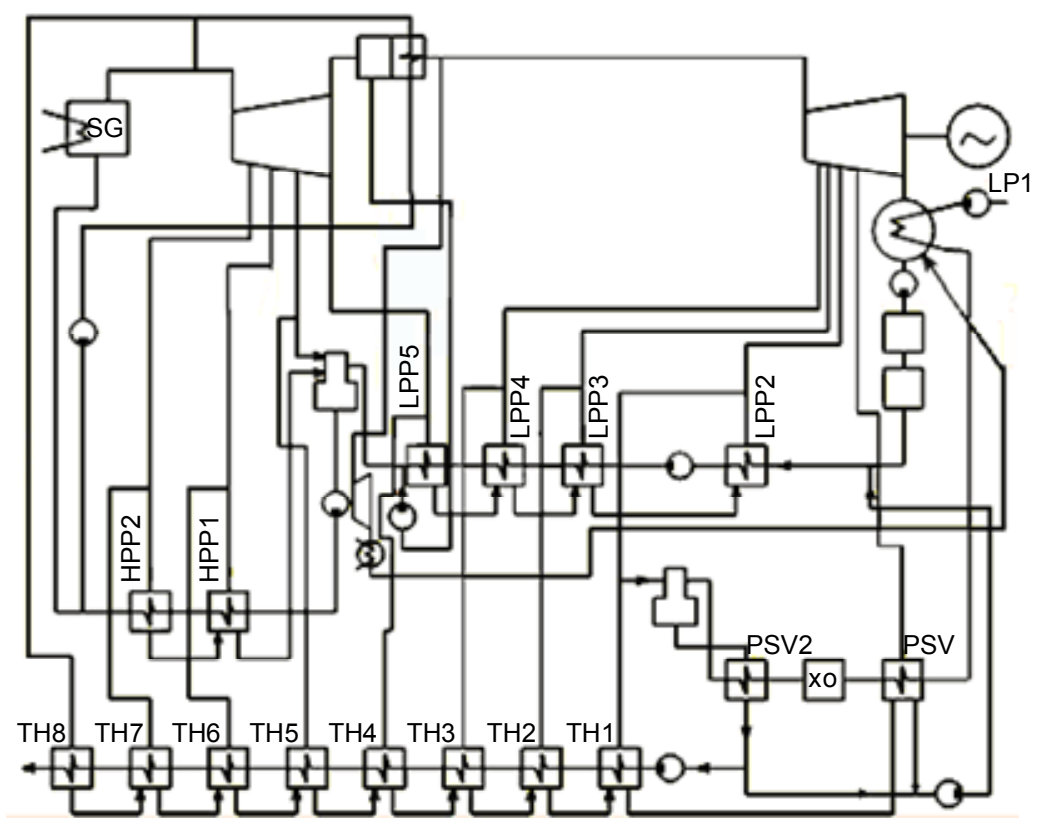

Fig. 2. The key diagram of turbine plant $K-1000-5,8 / 50$ with a cogeneration plant:

LPP - low-pressure preheater, HPP - high-pressure preheater, SG-steam generator, LP - line pump

As a result of the calculations of the design circuit of turbine plant K-1000-5,8/50 without cogeneration plant [11], we found that if steam feed rate is $5189 \mathrm{t} / \mathrm{h}$ then turbine plant capacity is $1022 \mathrm{MW}$. Cogeneration plant performs the following functions: heating water in the primarily condenser and in the raw water heater up to $50{ }^{\circ} \mathrm{C}$, chemical water treatment, feed-water preheating, deaeration and heating in eight technological heaters. In rated mode the turbine with cogeneration plant provides $675 \mathrm{t} / \mathrm{h}$ of technological coolant at temperature of $250^{\circ} \mathrm{C}$ and has electrical power 935.6 MW.

Results. The cost of the nuclear power complex for oil production consists of the costs of cogeneration plant, NPP, and heating network. The cost of cogeneration plant can be defined as the sum of the costs of technologic heaters and costs of strapping and installation (strapping and installation costs approximately $50 \%$ of the technologic heaters costs). The first three cascades of technologic heaters are made of steel mark 20. The other five - made of stainless steel (stainless steel in pipes in 7.36 times more expensive than carbon steel). Given that the cost of heat exchangers are not directly proportional to cost of pipe still, we decided that the cost of heat exchangers that made of stainless steel in 7 times greater than made of steel mark 20.

The cost of raw water heater PSV-200-7-15 is 53900 USD. Water flow consumption through the heater is $800 \mathrm{t} / \mathrm{h}$. Thus, each step of heating conventionally "contains" $\mu=675 / 800=0.84$ of heater.

The integrated value of technologic heaters is

$$
C_{T H}^{S U M}=C_{T H} \cdot n \cdot \mu+C_{T H} \cdot m \cdot z \cdot \mu
$$

where $C_{T H}$-the cost of raw water heater PSV-200-7-15;

$n$ - number of cascades of technologic heater that made of steel mark $20(n=3)$;

$m$ - number of cascades of technologic heater that made of stainless steel $(m=5)$;

$z$ - coefficient considering differences in the cost of raw water heater making from various types of steel $(z=7)$.

After substituting all known values, we got that

$$
C_{T H}^{S U M}=1.721 \cdot 10^{6} \text { USD. }
$$

The cost of the cogeneration plant, including installation costs, will be calculated as 


$$
S U M_{C}=1.5 \cdot C_{T H}^{S U M}=2.6 \cdot 10^{6} \text { USD. }
$$

Finally, including the costs of deaerator, raw water heater and chemical water treatment, the total cost of cogeneration plant will be calculated as

$$
S U M_{F I N}=1.5 \cdot S U M_{C}=3.9 \cdot 10^{6} \mathrm{USD} \text {. }
$$

The volume of additional oil will be

$$
V_{a d d}=V_{a} \cdot(\varepsilon-1),
$$

where $V_{a}-$ the annual output of Okhtyrka oilfield;

$\varepsilon$ - increasing coefficient of oil production with hot water pumping.

This coefficient was determined according to Table 4 [12]. Dependence can be described by polynomial of degree 6 :

$$
\varepsilon=-7.26 \cdot 10^{-13} t^{6}+8.77 \cdot 10^{-10} t^{5}-4.3 \cdot 10^{-7} t^{4}+1.1 \cdot 10^{-4} t^{3}-1.5 \cdot 10^{-2} t^{2}+1.1 t-30.9 .
$$

When the technological coolant temperature at the entrance to layer is $223.9{ }^{\circ} \mathrm{C}$, the coefficient $\varepsilon$ is 10.87 . Accordingly, the amount of additional oil will be $9.503 \cdot 10^{6} \mathrm{~m}^{3} /$ year. With oil price is at level of $31 \mathrm{USD} / \mathrm{bbl}$, the total profit from the sale of additional oil will be 1.853 billion USD.

Annual electricity supply can be determined by the formula

$$
E=N_{n} \cdot(1-b) \cdot T \cdot K,
$$

where $N_{n}$-nominal capacity of nuclear power unit;

$b$ - part of electricity that goes to its own needs, $b=9 \%$;

$T$ - number of hours in a year;

$K$ - capacity factor, $K=0.82$.

With cost of electricity is at level of $0.026 \mathrm{USD} / \mathrm{kWh}$, the profit from electricity sales will be 155.5 million USD.

Total annual profits will be 2.008 billion USD.

Table 4

Dependence of increasing coefficient of oil production with hot water pumping $(\varepsilon)$ on temperature of oil

\begin{tabular}{c|c|c|c|c|c|c|c|c}
\hline$t,{ }^{\circ} \mathrm{C}$ & 80 & 90 & 100 & 110 & 120 & 130 & 140 & 150 \\
\hline$\varepsilon$ & 1.206 & 2.031 & 2.425 & 2.862 & 3.342 & 3.866 & 4.433 & 5.044 \\
\hline$t,{ }^{\circ} \mathrm{C}$ & 160 & 170 & 180 & 190 & 200 & 210 & 220 & 230 \\
\hline$\varepsilon$ & 5.697 & 6.394 & 7.134 & 7.915 & 8.738 & 9.601 & 10.504 & 11.447 \\
\hline
\end{tabular}

Results of calculation of components of annual costs are summarized in Table 5.

Table 5

Components of annual costs

\begin{tabular}{l|c|c}
\hline \multicolumn{1}{c|}{ Item } & Value, million USD & Percentage, $\%$ \\
\hline Fuel & 28.7 & 3.037 \\
\hline Personnel costs & 2.4 & 0.254 \\
\hline General plant expenses & 68.96 & 7.297 \\
\hline Heating network & 0.423 & 0.0447 \\
\hline Water treatment & 2.155 & 0.228 \\
\hline Additional oil production & 304.1 & 32.18 \\
\hline Current investment & 528.047 & 55.9 \\
\hline Heating network maintenance costs & 10.292 & 1.089 \\
\hline Total & $\mathbf{9 4 5 . 0 7 7}$ & $\mathbf{1 0 0}$ \\
\hline
\end{tabular}


Thus, the annual profit (AP) from this manufacturing enterprise is expected to be about 1063.37 million USD.

Profitability of the nuclear power complex for oil production can be determined by the formula:

$$
P I=A P /\left(C_{N P P}+S U M_{F I N}+C_{T H}^{S U M}\right),
$$

where $C_{N P P}$ - cost of nuclear power unit (4.8 billion USD per unit) [15].

Profitability is PI $=22.15 \%$

Pay-back period is 4.5 years.

Conclusions. We developed and designed the key diagram of turbine plant K-1000-5,8/50 with a cogeneration plant which provide the technological coolant for injection into the wells.

We developed the scheme of the heating networks for delivering the technological coolant to the injection wells. Location of injection wells taken as contour thus thermal network consists of the six lines, which include pipelines between wells and injection pumps.

Heating of technological coolant is carried out (sequentially) in primarily condenser, in raw water heater - up to $50{ }^{\circ} \mathrm{C}$, in feed-water preheater, in deaerator, and finally - in eight technological heaters. In rated mode the turbine with cogeneration plant provides $675 \mathrm{t} / \mathrm{h}$ of technological coolant at temperature of $250{ }^{\circ} \mathrm{C}$ and has electrical power 935.6 MW.

As a result of calculating the profit from the sale of electricity and additional oil per year with account of annual operating costs, we determine that the profit equal to 1063.37 million USD.

According to the conducted analysis, we found that when the temperature of pumping coolant into a layer is $t=223.9^{\circ} \mathrm{C}$, the productivity of the nuclear power complex for oil production increases in 10.87 times.

Pay-back period of the nuclear power complex for oil production is 4.5 years.

\section{Література}

1. Recovery rates, enhanced oil recovery and technological limits / A. Muggeridge, A. Cockin, K. Webb, etc. // Philosophical Transactions of the Royal Society A: Mathematical, Physical and Engineering Sciences. - 2014. - Vol. 372. - P. 20120320.

2. Altunina, L.K. Improved oil recovery of high-viscosity oil pools with physicochemical methods and thermal-steam treatments / L.K. Altunina, V.A. Kuvshinov // Oil \& Gas Science and Technology Rev. IFP. - 2008. - Vol. 63, Issue 1. - PP. 37-8.

3. Butler, R.M. Thermal recovery of oil and bitumen / R.M. Butler. - Calgary: GravDrain Inc., 1997. - 528 p.

4. Verfondern, K. Potential for nuclear process heat application / K. Verfondern // Proceedings of an International Conference on Non-Electric Applications of Nuclear Power: Seawater Desalination, Hydrogen Production and Other Industrial Applications, 16-19 April 2007, Oarai, Japan. - Vienna: IAEA, 2009. - PP. 26-34.

5. Burger, J. Thermal methods of oil recovery / J. Burger, P. Sourieau, M. Combarnous. - Houston: Gulf, 1985. $-430 \mathrm{p}$.

6. Baibakov, N.K. Thermal methods of petroleum production / N.K. Baibakov, A.R. Garushev. - Amsterdam: Elsevier, 1989. - 209 p.

7. Клочко, Р.Ю. Економіко-організаційні аспекти реформування нафтогазового комплексу України (на прикладі НГВУ «Охтирканафтогаз») / Р.Ю. Клочко, Н.І. Коваль // Економіка і регіон. - 2012. - № 2(33). - C. 71-74.

8. Khatib, H. Financial and economic evaluation of projects in the electrical supply industry / H. Khatib. London: The Institution of Electrical Engineers, 1997. - 199 p.

9. Rajasekaran, V. Cost accounting / V. Rajasekaran, R. Lalitha. - Delhi: Pearson, 2011. - 819 p.

10. Абдул Хусейн, А.Р. Выбор схемы и диаметров трубопроводов тепловой сети для нефтяного месторождения / А.Р. Абдул Хусейн, В.П. Кравченко // Пр. Одес. політехн. ун-ту. - 2012. Вип. 2(39). - С. 130-135.

11. Киров, В.С. Тепловые схемы турбоустановок АЭС и их расчеты / В.С. Киров. - 2-е изд., испр. Одесса: Астропринт, 2004. - 212 с. 
12. Кравченко, В.П. Влияние температуры горячей воды, закачиваемой в нагнетательные скважины, на добычу нефти / В.П. Кравченко, А.Ю. Погосов, А.Р. Абдул Хусейн // Восточно-Европейский журнал передовых технологий. - 2013. - № 3/8 (63). - С. 35-39.

\section{References}

1. Muggeridge, A., Cockin, A., Webb, K., Frampton, H., Collins, I., Moulds, T., \& Salino, P. (2014). Recovery rates, enhanced oil recovery and technological limits. Philosophical Transactions of the Royal Society A: Mathematical, Physical and Engineering Sciences, 372, 20120320. DOI:10.1098/rsta.2012.0320

2. Altunina, L.K. \& Kuvshinov, V.A. (2008). Improved oil recovery of high-viscosity oil pools with physicochemical methods and thermal-steam treatments. Oil \& Gas Science and Technology Rev. IFP, 63(1), 37-48. DOI:10.2516/ogst:2007075

3. Butler, R.M. (1997). Thermal Recovery of Oil and Bitumen. Calgary: GravDrain Inc.

4. Verfondern, K. (2009). Potential for nuclear process heat application. In Proceedings of an International Conference on Non-Electric Applications of Nuclear Power: Seawater Desalination, Hydrogen Production and Other Industrial Applications (pp. 26-34). Vienna: IAEA.

5. Burger, J., Sourieau, P., \& Combarnous, M. (1985). Thermal Methods of Oil Recovery. Houston: Gulf.

6. Baibakov, N.K., \& Garushev, A.R. (1989). Thermal Methods of Petroleum Production. Amsterdam: Elsevier.

7. Klochko, R.Yu., \& Koval, N.I. (2012). Economic and organizational aspects of reforming the fuel and energy complex of Ukraine (on the example of "Okhtyrkanaftogas"). Economic and Region, 2, 71-74.

8. Khatib, H. (1997). Financial and Economic Evaluation of Projects in the Electrical Supply Industry. London: The Institution of Electrical Engineers.

9. Rajasekaran, V., \& Lalitha, R. (2011). Cost Accounting. Delhi: Pearson.

10. Abdul Husien, A.R., \& Kravchenko, V.P. (2012). Choosing the scheme and diameters of thermal network pipelines for an oilfield. Odes 'kyi Politechnichnyi Universytet. Pratsi, 2, 130-135.

11. Kirov, V.S. (2004). Heat Balance Diagrams of NPP Turbine Plants and their Calculations $\left(2^{\text {nd }}\right.$ Ed.). Odessa: Astroprint.

12. Kravchenko, V.P., Pogosov, O.Yu., \& Abdul Husien, A.R. (2013). Influence of hot water temperature pumped into force mining holes on output of oil. Eastern-European Journal of Enterprise Technologies, 3(8), 35-39. 